American Journal of Applied Sciences 6 (9): 1690-1700, 2009

ISSN 1546-9239

(C) 2009 Science Publications

\title{
The Removal of Methyl Red from Aqueous Solutions Using Banana Pseudostem Fibers
}

\author{
${ }^{1}$ Mas Rosemal H. Mas Haris and ${ }^{2}$ Kathiresan Sathasivam \\ ${ }^{1}$ School of Chemical Sciences, University Sains Malaysia, 11800 Minden, Penang, Malaysia \\ ${ }^{2}$ Department of Materials Science, Faculty of Applied Sciences, \\ AIMST University, Semeling 08100 Bedong, Kedah, Malaysia
}

\begin{abstract}
Problem statement: The aim of this study was to investigate the removal of methyl red, a mutagenic monoazo dye, from various aqueous solutions using banana pseudostem fibers of the size 212-350 micron. Approach: The parameters studied were the effect of $\mathrm{pH}$, amount of adsorbent, contact time, concentration of adsorbate and agitation speed. Results: Equilibrium data were fitted to the Langmuir and Freundlich isotherm models. The data were best represented by the latter with an adsorption capacity and adsorption intensity of 0.351 and 0.302 , respectively. Conclusion/Recommendations: Specific rate constants of the processes were calculated by kinetic measurements and a pseudo second order adsorption kinetics was obtained for all cases.
\end{abstract}

Key words: Sorption, methyl red, biotransformation, mutagenic, banana pseudostem fibers

\section{INTRODUCTION}

Rapid progress in industrial activities during recent years has led to the discharge of unprecedented amount of wastewater containing synthetic dyes, which pollutes the rivers and consequently causes harm to human and other living organisms. A majority of the used dyes are azo reactive dyes ${ }^{[1]}$. These are bright color dyes due to the presence of one or several azo $(-\mathrm{N}=\mathrm{N}$-) groups associated with substituted aromatic structures ${ }^{[2]}$. Effluents from textile, leather, food processing, cosmetics, paper and dye manufacturing industries are some examples of the sources of discharged azo dyes ${ }^{[3]}$. These dyes or their breakdown products are toxic to living organisms ${ }^{[4]}$. Furthermore, dyes in wastewater are difficult to remove because they are stable to light, heat and oxidizing agents. In short, they are not easily degradable ${ }^{[1,5]}$. In order to achieve a high degree of dye removal from wastewater systems, it is necessary to integrate biological, chemical and physical processes such as coagulation, ultra-filtration, electro-chemical adsorption and photo-oxidation ${ }^{[6]}$. Physical adsorption techniques are generally considered as the preferred means for removing and purifying organic substances due to their high efficiency and ability to separate a wide range of chemical compounds ${ }^{[7-11]}$.

The above reasons have prompted enormous research interest in the use of agricultural waste as starting materials because of their low-cost and widespread availability. Some examples of agrowaste that have been used for the removal of dyes are palm kernel fibers ${ }^{[12]}$, coir pith $^{[13]}$, sugarcane bagasse ${ }^{[14]}$, banana peel ${ }^{[15]}$, peanut hull ${ }^{[16]}$, rice bran and wheat $\operatorname{bran}^{[17]}$, rice husk ${ }^{[18]}$, tea waste ${ }^{[19]}$, waste apricot ${ }^{[20]}$, rubber seed coat ${ }^{[21]}$, coconut shell ${ }^{[22]}$, apple pomace and wheat straw ${ }^{[23]}$, halzelnut shell ${ }^{[24]}$, plum kernel ${ }^{[25]}$, corncob and barley husk ${ }^{[26]}$, bamboo ${ }^{[27]}$, grass waste ${ }^{[28]}$, pumpkin seed hull ${ }^{[29]}$ and garlic peel ${ }^{[30]}$.

Methyl Red (MR) is a commonly used monoazo dye in laboratory assays, textiles and other commercial products; however, it may cause eye and skin sensitization $^{[31]}$ and pharyngeal or digestive tract irritation if inhaled or swallowed ${ }^{[32]}$. Furthermore, MR is mutagenic under aerobic conditions: it undergoes biotransformation into 2-aminobenzoic acid and N-N'dimethyl-p-phenylene diamine $e^{[4,33-36]}$. Of late, there has been increasing interest to develop low-cost means ${ }^{[37]}$ of reducing the amount of, if not completely remove, MR in wastewater before being discharged into receiving water body.

Banana plants are of the family Musacease and cultivated primarily for their fruit. As such, after harvesting the fruit, the matured pseudostems are generally disposed at a landfill or left to decompose slowly in a plantation field. In the present study, application of the agrowaste, ground banana pseudostem fibers of the size 212-350 micron, for the removal of methyl red from various aqueous solutions has been studied.

Corresponding Author: Mas Rosemal Hakim Mas Haris, School of Chemical Sciences, University Sains Malaysia, Penang, Malaysia Tel: +06 046533563 Fax: +06 046574854 


\section{MATERIALS AND METHODS}

Sorbent: Banana pseudostems from the family of Musa acuminate $\times$ balbisiana Colla (ABB Group) $\mathrm{cv}$ 'Pisang Awak' were obtained locally. The pseudostems were chopped into cubes of average size of $2 \times 2 \mathrm{~cm}$. The cubes were boiled in distilled water for $1 \mathrm{~h}$ and then dried in an oven at $70^{\circ} \mathrm{C}$ until a constant weight was obtained. The resulting material was ground using a Warring Commercials high speed blender and sieved to isolate fibers of the size 212-350 micron.

Adsorbate: MR, 2-[4-(dimethylamino)phenylazo] benzoic acid, a dark red crystalline powder with a molecular weight of 269.30 and melting point 179$182^{\circ} \mathrm{C}$, was received from Bendosen-Laboratory Chemicals and used without further purification. The molecular structure of MR is shown in Fig. 1. MR is red in aqueous solution of $\mathrm{pH}$ under 4.4, yellow in $\mathrm{pH}$ over 6.2 and orange in between. A stock solution of MR $\left(500 \mathrm{mg} \mathrm{L}^{-1}\right.$ ) was prepared by dissolving $0.500 \mathrm{~g}$ of the dye in $1 \mathrm{~L}$ of distilled water and filtered via Whatman filter paper (No. 1). The prepared stock solution was then wrapped with aluminum foil and stored in a dark to prevent exposure to direct light.

pH study: The effect of $\mathrm{pH}$ was studied by agitating the fibers $(0.20 \mathrm{~g})$ in $50 \mathrm{~mL}$ of the stock solution using an orbital shaker at ambient temperature $\left(25-27^{\circ} \mathrm{C}\right)$. The experiment was conducted at $\mathrm{pH}$ value range 2-7. Agitation speed was kept constant at $150 \mathrm{rpm}$ for $120 \mathrm{~min}$, which was sufficient to reach equilibrium. Since MR is a pH dependent dye, the dye concentrations were measured by a single beam UV/vis spectrophotometer (Genesys 20 Thermo Spectronic, Krackeler Scientific, USA) at various wavelengths. The $\mathrm{pH}$ was adjusted by adding appropriate amount of either $0.1 \mathrm{M} \mathrm{NaOH}$ or $0.1 \mathrm{M}$ $\mathrm{HCl}$ solution before each experiment. The $\mathrm{pH}$ was measured by using a $\mathrm{pH}$ meter (Cyberscan 1500, EUTECH Instruments, India). When the equilibrium was established, the supernatant was carefully filtered through Whatman filter paper (No. 1) which was presaturated with distilled water. The maximum wavelength obtained for each desired $\mathrm{pH}$ value is shown in Table 1. It is worthwhile to note that no adsorption of MR occurred on the filter paper: A comparative study was done by measuring the concentration of the dye solution before and after filtering and the result showed no variation of concentration of the dye solution meaning that the amount of the dye adsorbed on the filter paper, if any, was negligible.

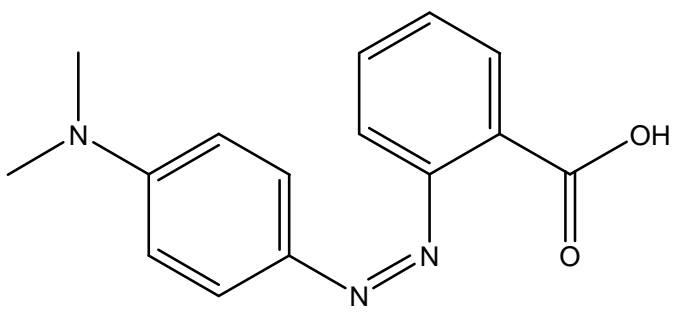

Fig. 1: Molecular structure of Methyl Red (MR)

Table 1: Optimal wavelength of MR solution at different $\mathrm{pH}$

\begin{tabular}{ll}
\hline $\mathrm{pH}$ & Optimal wavelength $(\mathrm{nm})$ \\
\hline 2 & 527 \\
3 & 525 \\
4 & 433 \\
5 & 403 \\
6 & 407 \\
7 & 420 \\
\hline
\end{tabular}

Contact time: Batch equilibrium studies were carried out by adding a fixed amount of the sorbent $(0.20 \mathrm{~g})$ into $250 \mathrm{~mL}$ Erlenmeyer flasks containing $50 \mathrm{~mL}$ of different initial concentrations $\left(50-500 \mathrm{mg} \mathrm{L}^{-1}\right)$ of dye solution at $\mathrm{pH} 3$. The flasks were agitated in an orbital shaker at $150 \mathrm{rpm}$ at ambient temperature for $120 \mathrm{~min}$. Aliquots $(5 \mathrm{~mL})$ were taken from the solutions and the concentrations were analyzed. The dye concentrations were measured at $525 \mathrm{~nm}$ at different contact times ( 0 , 15, 30, 45, 60, 90 and $120 \mathrm{~min}$ ). The adsorption at equilibrium, $\mathrm{q}_{\mathrm{e}}\left(\mathrm{mg} \mathrm{g}^{-1}\right)$, was calculated using Eq. 1:

$\mathrm{q}_{\mathrm{e}}=\left(\mathrm{C}_{\mathrm{o}}-\mathrm{C}_{\mathrm{e}}\right) \frac{\mathrm{V}}{\mathrm{W}}$

Where:

$\mathrm{C}_{\mathrm{o}}$ and $\mathrm{C}_{\mathrm{e}}\left(\mathrm{mg} \mathrm{L}^{-1}\right)=$ The liquid-phase concentrations of dye at initial and equilibrium, respectively

$\mathrm{V}$ $=$ The volume $(\mathrm{L})$ of the solution

$\mathrm{W} \quad=$ The weight $(\mathrm{g})$ of dry sorbent used

Optimization of amount of adsorbent: For the purpose of optimizing the amount of the adsorbent, experiments were performed by adding different weights of the fibers into $50 \mathrm{~mL}$ of the stock solution of $\mathrm{MR}$ at $\mathrm{pH} 3$ in a $250 \mathrm{~mL}$ Erlenmeyer flask and agitated for $120 \mathrm{~min}$ with a rotation speed of $150 \mathrm{rpm}$. The quantity of the fibers was varied between $0.1-0.3 \mathrm{~g}$ with an increment of $0.025 \mathrm{~g}$ to determine the optimum level of adsorption.

Concentration dependent study: The adsorption experiment related to the concentration of MR over a 
range of $50-500 \mathrm{mg} \mathrm{L}^{-1}$ at $\mathrm{pH} 3$ using $0.20 \mathrm{~g}$ of the fibers. This adsorption study was carried out in an orbital shaker agitated at $150 \mathrm{rpm}$ with $50 \mathrm{~mL}$ of the dye solution in a $250 \mathrm{~mL}$ Erlenmeyer flask.

Agitation study: Agitation speed variation plays an important role in determining the efficiency of the adsorption at different rotation speeds. The effect of agitation speed at 50,100,150, 200 and $250 \mathrm{rpm}$ on the adsorption was carried out. This study was carried using $50 \mathrm{~mL}$ of the MR stock solution at $\mathrm{pH} 3$ with the sorbent dose of $0.20 \mathrm{~g}$.

Spectroscopic study: Fourier Transform Infrared (FTIR) was used to identify the characteristic functional groups in the fibers. A known quantity $(5 \mathrm{mg})$ of the fibers sample was powdered and then dispersed in dry potassium bromide $(\mathrm{KBr})$. The mixture was thoroughly mixed in a mortar and pressed at pressure of 6 bars within 2 min to form a $\mathrm{KBr}$ thin disc. Then the disc was placed in a sample cup of a diffuse reflectance accessory. The IR spectrum was obtained using Perkin Elmer 2000 infrared spectrometer. The sample was scanned from $4000-400 \mathrm{~cm}^{-1}$ for 16 times to increase the signal to noise ratio.

Morphological analysis: The morphology of the fibers was observed using a Scanning Electron Microscopy (SEM) machine Model Leica Cambridge AS-360 at an accelerating voltage $15 \mathrm{kV}$. Prior to examination, the surface of the specimen was coated with a thin layer of gold approximately $30 \mathrm{~nm}$ using Sputter Coater Polaron SC 515.

\section{RESULTS AND DISCUSSION}

Effect of pH: The efficiency of sorption is dependent on the $\mathrm{pH}$ of the solution ${ }^{[37]}$ because variation in $\mathrm{pH}$ leads to the variation in the degree of ionization and the surface properties of the sorbent ${ }^{[38]}$. In view of this, comparative experiments were performed over a $\mathrm{pH}$ range 2.0-8.0 to obtain the optimum $\mathrm{pH}$ for dye adsorption. The result shown in Fig. 2 shows that the sorption of MR increased from the initial $\mathrm{pH} 2$ up to $\mathrm{pH} 3.0$ and then decreased over the $\mathrm{pH}$ range of 4-8. Therefore, all subsequent studies were carried out at $\mathrm{pH} 3$ as the optimum $\mathrm{pH}$. Malik ${ }^{[39]}$ and Mohamed $^{[40]}$ reported that at low $\mathrm{pH}$ region the surface of the fibers will be largely protonated. The positive ions $\left(\mathrm{H}^{+}\right)$provide an electrostatic attraction between the fibers surface and the dye molecules leading to maximum adsorption. On the other hand,

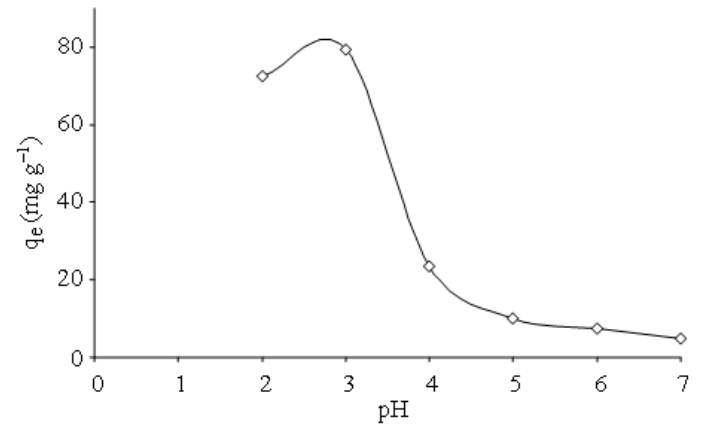

Fig. 2: Effect of $\mathrm{pH}$ on the adsorption of MR on banana pseudostem fibers $\left(\mathrm{C}_{0}=500 \mathrm{mg} \mathrm{L} \mathrm{L}^{-1}\right.$, temp. $=$ $25-27^{\circ} \mathrm{C}$, stirring rate $150 \mathrm{rpm}$, contact time 120 $\min$ and weight of fibers $=0.20 \mathrm{~g}$

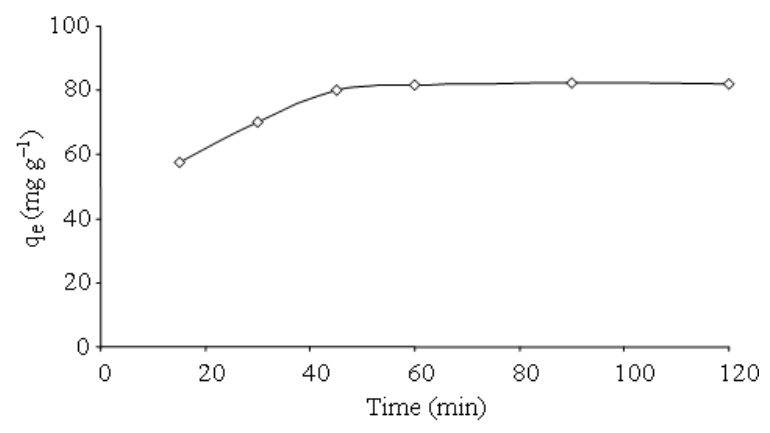

Fig. 3: Effect of contact time on the adsorption of MR on banana pseudostem fibers $\left(\mathrm{C}_{0}=500 \mathrm{mg} \mathrm{L}^{-1}\right.$, temp. $=25-27^{\circ} \mathrm{C}$, stirring rate $150 \mathrm{rpm}, \mathrm{pH} 3$ and weight of fibers $=0.20 \mathrm{~g}$ )

at $\mathrm{pH}$ above 3 (i.e., $\mathrm{pH}$ range of 4-8) the degree of protonation of the surface of the fibers will be less which result in the decrease in diffusion and adsorption thereby due to electrostatic repulsion ${ }^{[41,42]}$. Furthermore, lower adsorption of the direct dyes in alkaline medium can also be attributed to the competition from excess hydroxide ions $\left(\mathrm{OH}^{-}\right)$with the anionic dye molecules for the adsorption sites. In this study, we found that the biosorption was slightly unfavorable at $\mathrm{pH}$ lower than $\mathrm{pH}$ 3. This is attributed to the increase in $\mathrm{H}^{+}$ concentration leading to the formation of aqua complexes thereby retarding the dye sorption. Our finding agrees with that reported by Mohan et al. ${ }^{[43]}$.

Contact time study: The effect of contact time on the amount of MR adsorbed on the fibers was investigated at initial concentration of $500 \mathrm{mg} \mathrm{L}^{-1}$. The system was subjected to an agitation speed of $150 \mathrm{rpm}$ for $120 \mathrm{~min}$. Fig. 3 shows a rapid adsorption of the dye at the initial stages of the adsorption and equilibrium was attained 
within 45 min. Such uptake indicates a high degree of affinity towards the MR molecules via chemisorption $^{[44]}$.

Optimization of amount of adsorbent: Results shown in Fig. 4 indicate that the adsorbent dosage increases proportionately to the availability of the adsorbent sites. The increase of adsorbent sites and surface area of contact with the dyes increases the amount of dye uptakes and consequently leads to a better adsorption ${ }^{[5]}$. This observed trend is mainly due to the increase in sorptive surface area and availability of more adsorption site ${ }^{[45]}$.

Concentration dependent study: The results shown in Fig. 5 show that an increase in initial concentration enhances the interaction between the dye molecules and the surface of the fibers. The dye molecules have to encounter the boundary layer effect before diffusing from boundary layer film onto the adsorbent surface followed by the diffusion of the dye into the porous structure of the adsorbent which eventually will take relatively longer contact time. The time profile of the dye uptake by the adsorbent is a single, smooth and continuous curve leading to a saturation point ${ }^{[41]}$. In addition, increasing the initial dye concentration increases the number of collisions between dye molecules and the adsorbent, which enhances the adsorption process.

Agitation Study: The effect of agitation speed on the dye adsorption at the adsorbent dosage of $0.20 \mathrm{~g}$, initial dye concentration of $500 \mathrm{mg} \mathrm{L}^{-1}$, $\mathrm{pH} 3$ listed in Table 2 . The data indicate that the adsorption capacity $\left(\mathrm{q}_{\mathrm{e}}\right)$ increased as the agitation speed increased from 50-150 $\mathrm{rpm}$. However, the $\mathrm{q}_{\mathrm{e}}$ values at the agitation speeds of 150,200 and $250 \mathrm{rpm}$ are fairly the same suggesting that the effect of agitation has plateaued at about 150 rpm. This effect can be attributed to the increase in turbulence and the decrease in boundary layer thickness around the adsorbent particles as a result of increase in the degree of mixing ${ }^{[46]}$. This result is also in agreement with that reported by Al-Qodah ${ }^{[47]}$ and Ho et al. ${ }^{[48]}$, for the adsorption of dyes onto activated clay and shale oil ash, respectively.

Adsorption isotherms: An adsorption isotherm indicates how adsorbed molecules distribute between the liquid phase and the solid phase when the adsorption process reaches an equilibrium state. The analysis of the isotherm data by fitting them to different isotherm models is an important step to find the suitable

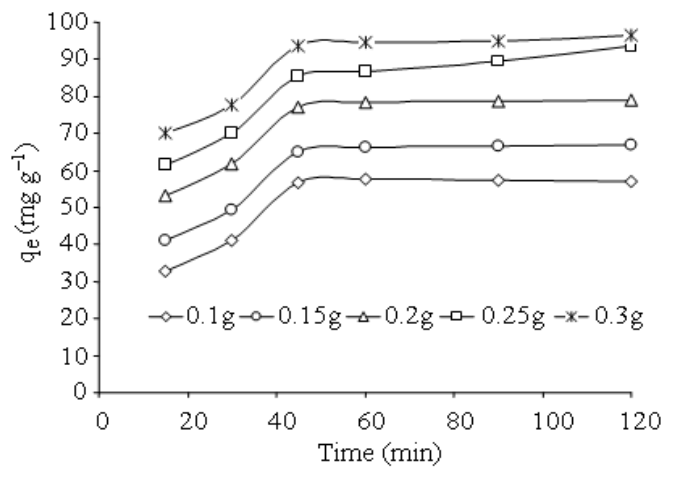

Fig. 4: Effect of adsorbent dose on the adsorption of MR on banana pseudostem fibers $\left(\mathrm{C}_{0}=500 \mathrm{mg} \mathrm{L}^{-1}\right.$, Temp. $=25-27^{\circ} \mathrm{C}$, stirring rate $150 \mathrm{rpm}$ and $\mathrm{pH} 3$ )

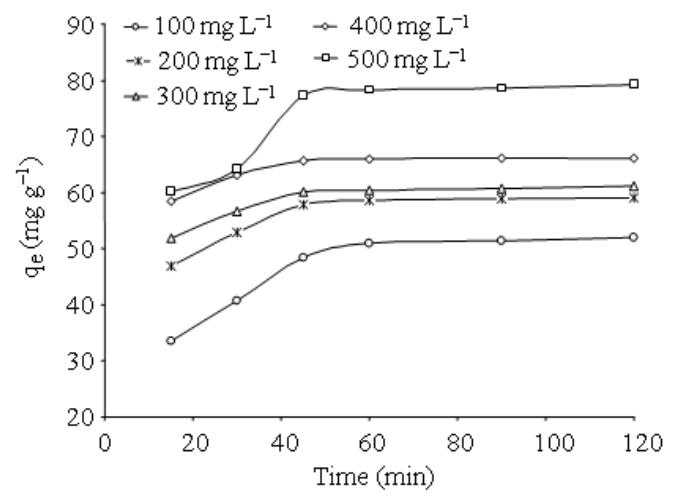

Fig. 5: Effect of MR concentration on the adsorption of MR on banana pseudostem fibers (weight of fibers $=0.20 \mathrm{~g}$, Temp. $=25-27^{\circ} \mathrm{C}$, stirring rate $150 \mathrm{rpm}$ and $\mathrm{pH} \mathrm{3}$ )

Table 2: $\mathrm{q}_{\mathrm{e}}$ and $\mathrm{R}^{2}$ parameters for the adsorption of MR on banana pseudostem fibers (Weight $=0.20 \mathrm{~g}$, ambient temperature, concentration $500 \mathrm{mg} \mathrm{L}^{-1}$ and $\mathrm{pH} 3$ )

\begin{tabular}{ll}
\hline Agitation rate $(\mathrm{rpm})$ & $\mathrm{q}_{\mathrm{e}}\left(\mathrm{mg} \mathrm{g}^{-1}\right)$ \\
\hline 0 & 66.58 \\
50 & 71.06 \\
100 & 75.56 \\
150 & 78.94 \\
200 & 84.28 \\
250 & 87.64 \\
\hline
\end{tabular}

model that can be used for design purposes ${ }^{[49]}$. Adsorption isotherm is basically important to describe how solutes interact with adsorbents and is critical in optimizing the use of adsorbents. In this study, adsorption isotherm study was carried out on two isotherm models: Langmuir and Freundlich. The applicability of the isotherm models to the adsorption study done was compared by judging the correlation coefficients, $\mathrm{R}^{2}$ values. 
Langmuir isotherm model: Langmuir isotherm model assumes the uniform energies of adsorption onto the surface and no transmigration of adsorbate in the plane of the surface. Langmuir sorption is a model based on the physical hypothesis that there are no interaction between adsorbed molecules and the adsorption energy over the entire coverage surface. Also there is no transmigration of the adsorbate in the plane of the surface of the adsorbent ${ }^{[50]}$. On the other hand in the Langmuir model, it is assumed that intermolecular forces decrease rapidly with distance and this lead to the prediction that coverage of the banana pseudostem fibers is of monolayer type. Once a particular site of the adsorbent is occupied by an adsorbate molecule, no further adsorption takes place at that site. The linear form of Langmuir isotherm equation is given in Eq. 2.

$$
\frac{\mathrm{C}_{\mathrm{e}}}{\mathrm{q}_{\mathrm{e}}}=\frac{1}{\mathrm{Q}_{0} \mathrm{~b}}+\frac{1}{\mathrm{Q}_{0}} \mathrm{C}_{\mathrm{e}}
$$

Where:

$$
\begin{aligned}
& \mathrm{C}_{\mathrm{e}}=\text { The equilibrium concentration of the } \\
& \text { adsorbate }\left(\mathrm{mg} \mathrm{L}^{-1}\right) \\
& \mathrm{q}_{\mathrm{e}}=\text { The amount of adsorbate adsorbed per }
\end{aligned}
$$

When $\mathrm{C}_{\mathrm{e}} / \mathrm{q}_{\mathrm{e}}$ was plotted against $\mathrm{C}_{\mathrm{e}}$, a straight line with slope of $1 / \mathrm{Q}_{\mathrm{o}}$ was obtained, as shown in Fig. 6 . The value of $\mathrm{Q}_{0}$ was determined from the Langmuir plot at the concentration range $100-500 \mathrm{mg} \mathrm{L}^{-1}$ as 88.50 and then the $b$ value was calculated to be 0.05 . The correlation coefficient of Langmuir isotherm, $R^{2}$ is 0.983 .

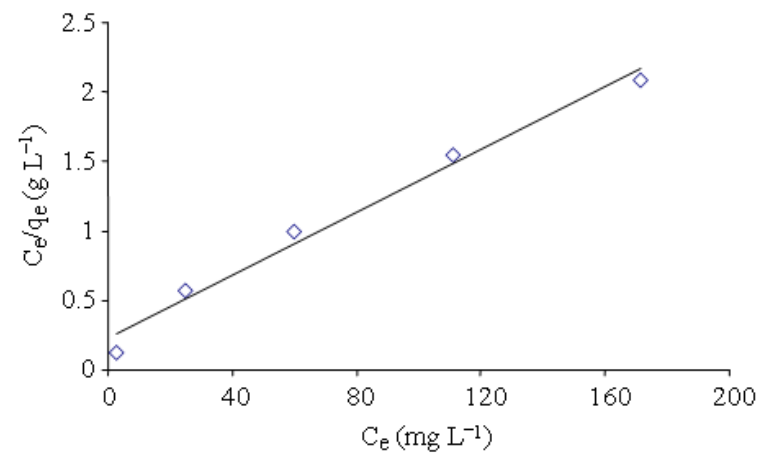

Fig. 6: Langmuir isotherm for MR sorption onto banana pseudostem fibers at ambient temperature $\left(25-27^{\circ} \mathrm{C}\right)$

The essential characteristics of the Langmuir isotherm can be expressed in terms of a dimensionless constant separation factor $R_{L}$ that is given in Eq. 3:

$$
\mathrm{R}_{\mathrm{L}}=\frac{1}{1+\mathrm{bC}_{0}}
$$

The value of $\mathrm{R}_{\mathrm{L}}$ indicates the type of the isotherm to be either favorable $\left(0<\mathrm{R}_{\mathrm{L}}<1\right)$, unfavorable $\left(\mathrm{R}_{\mathrm{L}}>1\right)$, linear $\left(R_{L}=1\right)$ or irreversible $\left(R_{L}=0\right)$. The value of $R_{L}$ was found to be 0.0385 suggesting the isotherm to be favorable at the concentrations studied.

Freundlich isotherm model: This model considers a heterogeneous adsorption surface that has unequal available sites with different energies of adsorption ${ }^{[51]}$ and can be represented by Eq. 4:

$$
\ln \mathrm{q}_{\mathrm{e}}=\ln \mathrm{K}_{\mathrm{f}}+\frac{1}{\mathrm{n}}\left(\ln \mathrm{C}_{\mathrm{e}}\right)
$$

Where:

$\mathrm{C}_{\mathrm{e}}$

$\mathrm{q}_{\mathrm{e}}$

$\mathrm{K}_{\mathrm{f}} \quad=$ The adsorption capacity of the

$\mathrm{K}_{\mathrm{f}}\left(\mathrm{mg} \mathrm{g}^{-1}\right)$ and $\mathrm{n}=$ Freundlich constants with $\mathrm{n}$ giving an indication of how favorable the adsorption process adsorbent

$\mathrm{K}_{\mathrm{f}}$ can be defined as the adsorption or distribution coefficient and represents the quantity of dye adsorbed onto the fibers for a unit equilibrium concentration. The slope of $1 / \mathrm{n}$ ranging between 0 and 1 is a measure of adsorption intensity or surface heterogeneity, becoming more heterogeneous as its value gets closer to zero ${ }^{[52]}$. Figure 7 clearly reveals that for the adsorbents $\log \mathrm{q}_{\mathrm{e}}$ versus $\log \mathrm{C}_{\mathrm{e}}$ plots are linear. The Freundlich constants were derived from the slopes and intercepts of $\log \mathrm{C}_{\mathrm{e}}$ versus $\log \mathrm{q}_{\mathrm{e}}$ and are shown in Table 3. By analyzing the Freundlich isotherm, it describes the heterogeneous system and reversible adsorption. However, the adsorption is not restricted to a monolayer formation but the model predicts that dye concentration in the adsorbent will increase with increase in dye concentration in the solution. Theoretically, adsorbent has finite number of sites and once all these sites are occupied by adsorbed molecules further adsorption cannot take place. 
Table 3: Langmuir and Freundlich isotherm constants and correlation coefficients for adsorption of MR on banana pseudostem fibers at ambient temperature

\begin{tabular}{lc}
\hline Isotherms & Parameters \\
\hline Langmuir: & \\
$\mathrm{Q}_{0}\left(\mathrm{mg} \mathrm{g}^{-1}\right)$ & 88.50 \\
$\mathrm{~b}\left(\mathrm{mg} \mathrm{L}^{-1}\right)$ & 0.050 \\
$\mathrm{R}^{2}$ & 0.983 \\
Freundlich: & \\
$\mathrm{K}_{\mathrm{f}}\left(\mathrm{mg} \mathrm{g}^{-1}\right)$ & 17.25 \\
$\mathrm{n}$ & 3.310 \\
$\mathrm{R}^{2}$ & 0.998 \\
\hline
\end{tabular}

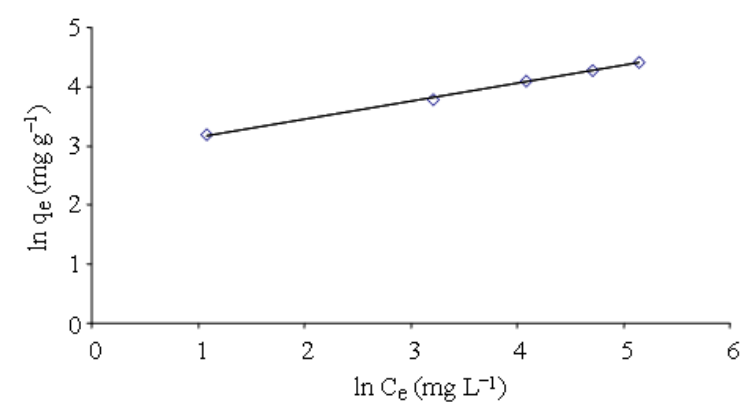

Fig. 7: Freundlich isotherm for MR sorption onto banana pseudostem fibers at ambient temperature $\left(25-27^{\circ} \mathrm{C}\right)$

As seen from the Table 3, a high regression correlation coefficient, $\mathrm{R}^{2}(0.998)$ was shown by the Freundlich model. This indicates that the Freundlich model was suitable for describing the sorption equilibrium of MR by the banana pseudostem fibers. From the plot shown in Fig. 7 , the $K_{f}$ value and $n$ value was recorded at 17.25 and 0.302 , respectively. When the linearity of the plots of the Freundlich and Langmuir models was compared, it is found that the former has a better fit. Thus it is reasonable to conclude that the adsorption of MR on the fibers that consist of heterogeneous adsorption sites that are similar to each other in respect of adsorption phenomenon.

Adsorption kinetics: Two simplified kinetic models were adopted to examine the mechanism of the adsorption process. First, the kinetics of adsorption was analyzed by the Lagergren pseudo-first-order equation $^{[53]}$ as depicted in Eq. 5:

$\log \left(q_{e}-q_{t}\right)=\log q_{e}-\frac{k_{1} t}{2.303}$

Where:

$\mathrm{q}_{\mathrm{e}}$ and $\mathrm{q}_{\mathrm{t}}=$ The amounts of MR adsorbed $\left(\mathrm{mg} \mathrm{g}^{-1}\right)$ at equilibrium and at time $\mathrm{t}$ ( $\mathrm{min})$, respectively

$\mathrm{k}_{1}\left(\min ^{-1}\right)=$ The rate constant

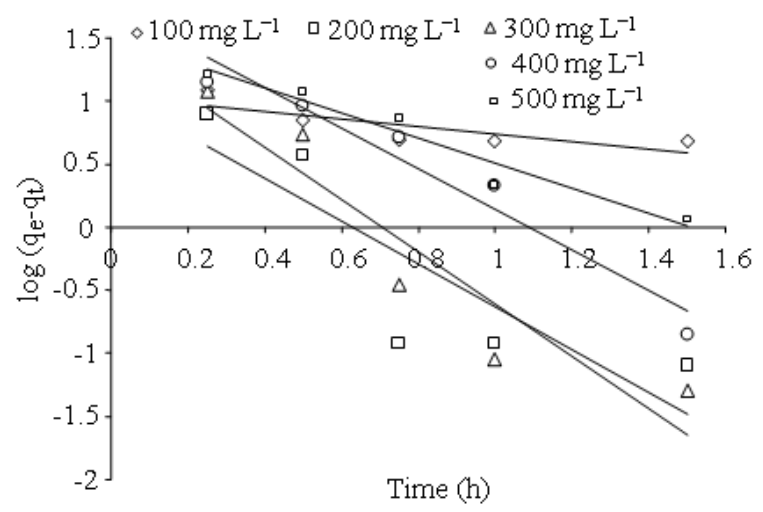

Fig. 8: Pseudo first order for MR sorption onto banana pseudostem fibers at ambient temperature (25$27^{\circ} \mathrm{C}$ )

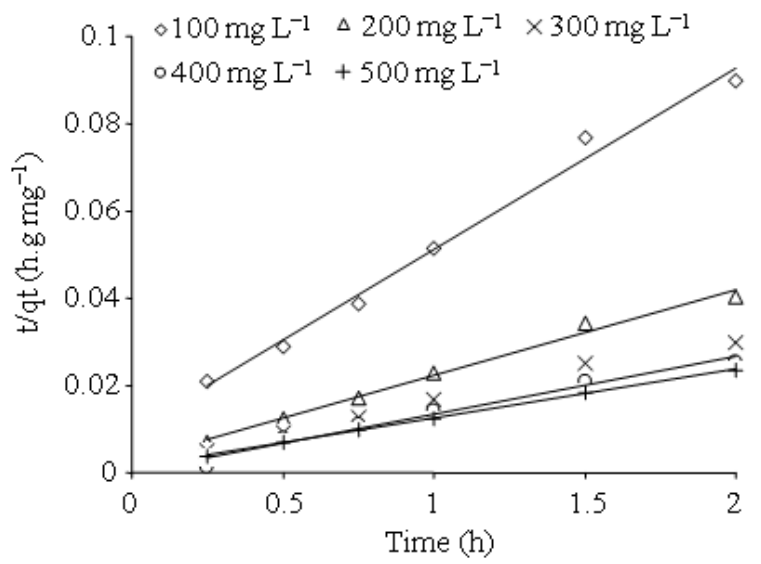

Fig. 9: Pseudo second order for MR sorption onto banana pseudostem fibers at ambient temperature $\left(25-27^{\circ} \mathrm{C}\right)$

Values of $\mathrm{k}_{1}$ at ambient temperature were calculated from the plots of $\log \left(\mathrm{q}_{\mathrm{e}}-\mathrm{q}_{\mathrm{t}}\right)$ versus $\mathrm{t}$ (Fig. 8) for different initial concentrations of MR. The set of $\mathrm{R}^{2}$ values obtained were poor and the experimental $\mathrm{q}_{\mathrm{e}}$ values did not agree with the calculated values obtained from the linear plots (Table 4). On the other hand, the pseudo-second-order equation based on equilibrium adsorption $^{[54]}$ is expressed as Eq. 6:

$\frac{\mathrm{t}}{\mathrm{q}_{\mathrm{t}}}=\frac{1}{\mathrm{k}_{2} \mathrm{q}_{\mathrm{e}}^{2}}+\frac{1}{\mathrm{q}_{\mathrm{e}}} \mathrm{t}$

where, $\mathrm{k}_{2}\left(\mathrm{~g} \mathrm{mg}^{-1} \mathrm{~min}\right)$ is the rate constant of secondorder adsorption. The linear plot of $t / q_{t}$ versus $t$ at ambient temperature, as shown in Fig. 9, yielded set of 
Am. J. Applied Sci., 6 (9): 1690-1700, 2009

Table 4: Comparison of the pseudo-first-order, pseudo-second-order adsorption rate constants and calculated and experimental $\mathrm{q}_{\mathrm{e}}$ values obtained at different initial MR concentrations

\begin{tabular}{|c|c|c|c|c|c|c|c|}
\hline \multirow[b]{2}{*}{ Initial concentrations $\left(\mathrm{mg} \mathrm{L}^{-1}\right)$} & \multirow[b]{2}{*}{$\mathrm{q}_{\mathrm{e}(\operatorname{Exp})}$} & \multicolumn{3}{|c|}{ Pseudo first order kinetic model } & \multicolumn{3}{|c|}{ Pseudo second order kinetic model } \\
\hline & & $\mathrm{k}_{1}$ & $\mathrm{q}_{\mathrm{e}(\mathrm{Cal})}$ & $\mathrm{R}^{2}$ & $\mathrm{k}_{2}$ & $\mathrm{q}_{\mathrm{e}(\mathrm{Cal})}$ & $\mathrm{R}^{2}$ \\
\hline 100 & 24.27 & 0.829 & 11.90 & 0.849 & 0.185 & 23.980 & $\overline{0.990}$ \\
\hline 200 & 43.80 & 3.915 & 11.65 & 0.741 & 0.137 & 51.020 & 0.990 \\
\hline 300 & 60.03 & 4.756 & 28.41 & 0.876 & 0.111 & 68.970 & 0.993 \\
\hline 400 & 72.18 & 3.703 & 55.78 & 0.830 & 0.581 & 75.760 & 0.971 \\
\hline 500 & 82.41 & 2.251 & 29.72 & 0.977 & 0.098 & 88.500 & 0.999 \\
\hline
\end{tabular}

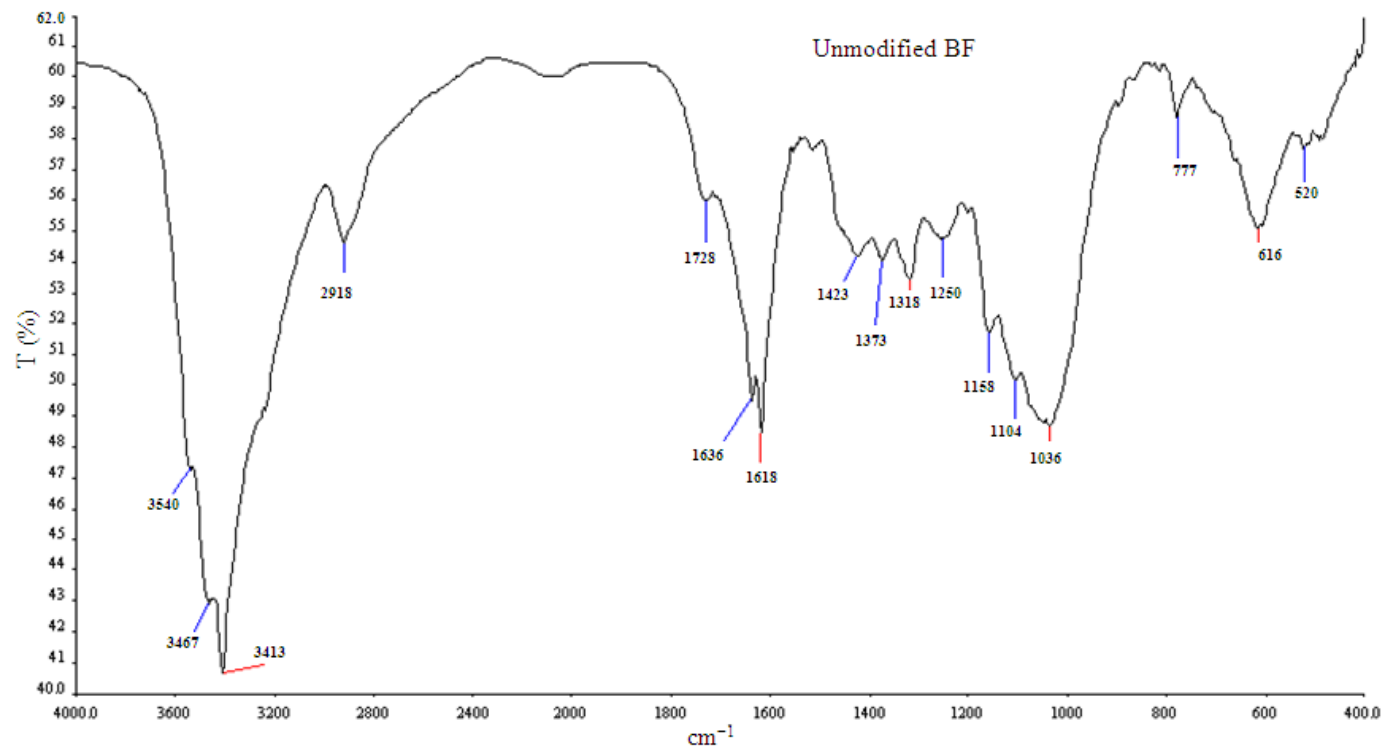

Fig. 10: Infrared spectra of banana pseudostem fibers

$\mathrm{R}^{2}$ values that are greater than 0.970 for all $\mathrm{MR}$ concentrations. It also showed a good agreement between the experimental and the calculated $\mathrm{q}_{\mathrm{e}}$ values (Table 4), indicating the applicability of this model to describe the adsorption process of MR onto the fibers.

Spectroscopic study: The aim of using FTIR analysis is to determine the existence of functional groups that exists on the fibers. The IR spectrum of banana pseudostem fibers in the form of $\mathrm{KBr}$ pallet is shown in Fig. 10. Identification of the characteristic peaks is based on previous studies of banana and coconut fibers ${ }^{[55]}$, sugarcane bagasse cellulose ${ }^{[56]}$, rice straw $^{[57]}$, perennial ryegrass leaves ${ }^{[58]}$ and hemicellulose, cellulose and $\operatorname{lignin}^{[59]}$. The typical functional groups and their corresponding IR signals are listed in Table 5. The absorptions at $3540,3467,3413$ and $3238 \mathrm{~cm}^{-1}$ are due to the stretching of hydroxyl groups of cellulose, hemicellulose and lignin that are present in the banana pseudostem fibers. The medium strong band at $2918 \mathrm{~cm}^{-1}$ is due to the $\mathrm{C}-\mathrm{H}$ stretching of saturated $\left(\mathrm{sp}^{3}\right)$ carbon.
Table 5: Infrared spectrum data of banana pseudostem fibers

\begin{tabular}{ll}
\hline Frequency, $\mathrm{cm}^{-1}$ & Assignment \\
\hline $3540 \mathrm{w}, 3467 \mathrm{w}, 3413 \mathrm{~s}, 3238 \mathrm{vw}$ & OH stretching \\
$2918 \mathrm{~ms}$ & C-H stretching \\
$1728 \mathrm{w}$ & $\mathrm{C}=\mathrm{O}$ stretching \\
$1636 \mathrm{~ms}$ & O-H bending (of $\left.\mathrm{H}_{2} \mathrm{O}\right)$ \\
$1618 \mathrm{~s}$ & $\mathrm{C}=\mathrm{C}$ stretching \\
$1423 \mathrm{w}$ & $\mathrm{CH}_{2}$ bending \\
$1373 \mathrm{w}$ & O-H bending \\
$1318 \mathrm{w}$ & C-C and C-O stretching \\
$1250 \mathrm{w}$ & C-O stretching \\
$1158 \mathrm{w}$ & C-O antisymmetric stretching \\
$1104 \mathrm{w}$ & C-O-H $(\mathrm{OH}$ association) \\
$1036 \mathrm{w}$ & C-O-C stretching (pyranose \\
& ring skeletal) \\
\hline
\end{tabular}

w: weak; s: strong; vw: very weak; ms: medium strong

The weak band at $1728 \mathrm{~cm}^{-1}$ corresponds to the absorption of carbonyl group of carboxylic acids of the hemicellulose which is a minor component of the fibers. The band at $1636 \mathrm{~cm}^{-1}$ is assigned to the bending mode of absorbed water since fibers with hemicellulose component are known to have a strong affinity for water ${ }^{[58,60]}$. The band at $1618 \mathrm{~cm}^{-1}$ is due to $\mathrm{C}=\mathrm{C}$ stretching associated with the aromatic skeletal mode of fibers containing lignin ${ }^{[59]}$. The weak bands at 1423 , 


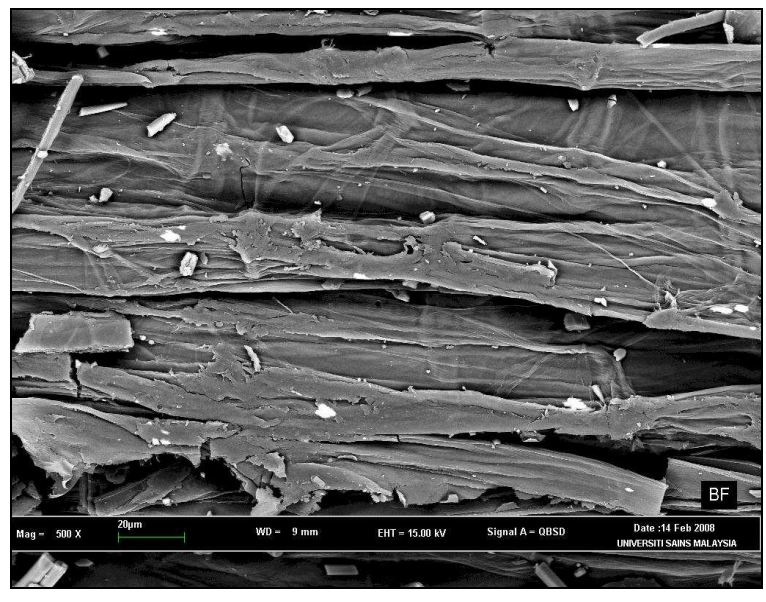

Fig. 11: SEM micrograph of banana pseudostem fibers

1373 and $1250 \mathrm{~cm}^{-1}$ are assigned to $\mathrm{C}-\mathrm{H}$ bending, $\mathrm{C}-\mathrm{O}$ stretching and $\mathrm{O}-\mathrm{H}$ bending, respectively ${ }^{[60]}$. The bands at 1318 and $1158 \mathrm{~cm}^{-1}$ are assigned to $\mathrm{O}-\mathrm{H}$ bending and $\mathrm{C}-\mathrm{O}$ skeletal vibrations, respectively.

Morphological analysis: Studies of the fibers surface topography could provide vital information on the level of interfacial adhesion that would exist between the fibers and the dye molecules. Figure 11 shows the SEM micrograph of the banana pseudostem fibers. Some minor impurities can be observed as tiny white specks on the surface of the fibers. On the whole, however, the surface of the fibers appears to be clean but with fairly rough texture which is ideal for surface adsorption. Bilba et al. ${ }^{[5]}$ reported that the banana pseudostem fibers were made of rough particles. Each particle was formed of hollow not cylindrical fibers whose walls presented hazardous porosities whose size is smaller than $1 \mu \mathrm{m}$. The walls which made of fibrils embedded in a homogeneous matrix. The fibrils were probably composed of cellulose that constitutes the skeleton of cellular wall, the homogenous matrix a mixture of various polysaccharide acids, neutral hemicelluloses and lignin.

\section{CONCLUSION}

The use of ground banana pseudostems fibers of the size 212-350 micron for the removal of MR from aqueous solutions was investigated. The effect of various parameters such as $\mathrm{pH}$, sorbent dose, contact time, dye concentration and agitation speed was studied. The kinetics of direct dye adsorption of MR on the banana pseudostem fibers follows the pseudo-secondorder model. The equilibrium data fit well in the
Freundlich model of adsorption, which suggests a heterogeneous coverage of the dye molecules at the outer surface of the fibers. The present research demonstrates that banana pseudostems, which are abundantly available but generally discarded as agricultural waste, can be utilized as efficient sorbents for the removal of MR from aqueous solutions.

\section{ACKNOWLEDGEMENT}

The researchers are thankful to the Ministry of Science, Technology and Innovation, Malaysia for providing the funds. They are also grateful to the School of Chemical Sciences, University Sains Malaysia and the Department of Materials Science, Faculty of Applied Sciences, AIMST University for providing the space and facilities for conducting the research.

\section{REFERENCES}

1. Leechart, P., W. Nakbanpote and P. Thiravetyan, 2009. Application of 'waste' wood-shaving bottom ash for adsorption of azo reactive dye. J. Environ. Manage., 90 : 912-920. DOI: 10.1016/j.jenvman.2008.02

2. Forgacs, E., T. Cserhatia and G. Oros, 2004. Removal of synthetic dyes from wastewaters: A review. Environ. Int., 30: 953-971. DOI: 10.1016/j.envint.2004.02.001

3. Bhatnagar, A. and A.K. Jain, 2005. A comparative adsorption study with different industrial wastes as adsorbents for the removal of cationic dyes from water. J. Colloid Interface Sci., 281: 49-55. DOI: 10.1016/j.jcis.2004.08.07

4. Chung, K.T., G.E. Fulk and A.W. Andrews, 1981. Mutagenicity testing of some commonly used dyes. Applied Environ. Microbiol., 42: 641-648. http://www.scopus.com/scopus/record/display.url? eid=2-s2.0-

$0019776565 \&$ view $=$ basic $\&$ origin $=$ inward $\&$ txGid $=$ KyyFiDmjoh7pi0ucIjhWIag\%3a8

5. Jain, R. and S. Sikarwar, 2008. Removal of hazardous dye congored from waste material. J. Hazard. Mater., 152: 942-948. DOI: 10.1016/j.jhazmat.2007.07.070

6. Kargi, F. and S.S. Ozmihci, 2004. Biosorption performance of powdered activated sludge for removal of different dyestuffs. Enz. Microb. Technol., $\quad 35$ : 267-271. DOI: 10.1016/j.enzmictec.2004.05.002 
7. Imamura, K., E. Ikeda, T. Nayayasu and K. Nakanishi, 2002. Adsorption behavior of methylene blue and its congeners on a stainless steel surface. J. Colloid Inter. Sci., 245: 50-57. DOI:10.1006/jcis.2001.7967

8. Gemeay, A.H., A.S. El-Sherbiny and A. Zaki, 2002. Adsorption and kinetic studies of the intercalation of some organic compounds onto $\mathrm{NaC}$ montmorillonite. J. Colloid Inter. Sci., 245: 116-125. DOI: $10.1006 /$ jcis. 2001.7989

9. Holzheu, S. and H. Hoffmann, 2002. Adsorption study of cationic dyes having a trimethylammonium anchor group on hectorite using electrooptic and spectroscopic methods. J. Colloid Inter. Sci., 245: 16-23. DOI:10.1006/jcis.2001.7978

10. Ofomaja, A.E. and Y.S. Ho, 2006. Equilibrium sorption of anionic dye from aqueous solution by palm kiner fiber as sorbent. Dyes Pigment., 74: 60-66. DOI: 10.1016/j.dyepig.2006.01.014

11. Ho, Y.S., T.H. Chiang and Y.M. Hsueh, 2003. Removal of basic dye from aqueous solution using tree fern as a biosorbent. Process Biochem., 40: 119-124. DOI: 10.1016/j.procbio.2003.11.035

12. Ofomaja, A.E., 2008. Kinetics and mecanisim of methylene blue sorption onto palm kernal fiber. Biochem. Eng. J., 40: 16-24. DOI: 10.1016/j.procbio.2006.07.005

13. Namasivayam, C., M. Dinesh Kumar, K. Selvi, R.A. Begum, T. Vanathi and R.T. Yamuna, 2001. 'Waste' coir pith-a potential biomass for the treatment of dyeing wastewaters. Biomass Bioenergy, 31: 477-483. DOI: 10.1016/S09619534(01)00052-6

14. Azahar, S., A.G. Liew, D. Suhardy, K.F. Hafiz and M.D.I. Hatim, 2005. Dye Removal from aqueous solution by using adsorption on treated sugarcane bagasse. Am. J. Applied Sci. 2: 1499-1503. http://www.scipub.org/scipub/detail_issue.php?V_ No=169\&j_id=ajas.

15. Annadurai, G., R. Juang and D. Lee, 2002. Use of cellulose-based wastes for adsorption of dyes from aqueous solutions. J. Hazard. Mater., 92: 263-274. DOI: 10.1016/S0304-3894(02)00017-1

16. Gong, R.M., Y. Ding, M. Li, C. Yang, H.J. Liu and Y.Z. Sun, 2005. Utilization of powdered peanut hull as biosorbent for removal of anionic dyes from aqueous solution. Dyes Pigment., 64: 187-194. DOI: 10.1016/j.dyepig.2004.05.005

17. Xue, S.W., Z. Yin. J. Yu and S. Cheng, 2008. The removal of basic dyes from aqueous solutions using agricultural by-products. J. Hazard. Mater. 157: 374-385. DOI: 10.1016/j.jhazmat.2008.01.004
18. Lakshmi, U.R., V.C. Srivastava, I.D. Mall and D.H. Lataye, 2009. Rice husk ash as an effective adsorbent: Evaluation of adsorptive characteristics for Indigo Carmine dye. J. Environ. Manage., 90: 710-720. DOI: 10.1016/J.JENVMAN.2008.01.002

19. Tamez Uddin, M., M. Akhtarul Islam, S. Mahmud and M. Rukanuzzaman, 2009. Adsorptive removal of methylene blue by tea waste. J. Hazard. Mater., 164: 53-60. DOI: 10.1016/j.jhazmat.2008.07.131

20. Onal, Y., C. Akmil-Basar and C. Sarici-Ozdemir, 2007. Elucidation of the naproxen sodium adsorption onto activated carbon prepared from waste apricot: Kinetic, equilibrium and thermodynamic characterization. J. Hazard. Mater., 148: 727-734. DOI: 10.1016/j.jhazmat.2007.03.037

21. Hameed, B.H. and F.B.M. Daud, 2008. Adsorption studies of basic dye on activated carbon derived from agricultural waste: Hevea brasiliensis seed coat. Chem. Eng. J., 139: 48-55. DOI: 10.1016/j.cej.2007.07.089

22. Singh, K.P., A. Malik, S. Sinha and P. Ojha, 2008. Liquid-phase adsorption of phenols using activated carbons derived from agricultural waste material. J. Hazard. Mater., 150: 626-641. DOI: 10.1016/j.jhazmat.2007.05.017

23. Robinson, T., B. Chandran and P. Nigam, 2002. Removal of dyes from a synthetic textile dye effluent by biosorption on apple pomace and wheat straw. Water Res., 36: 2824-2830. DOI: 10.1016/S0043-1354(01)00521-8

24. Doğan, M., H. Abak and M. Alkan, 2009. Adsorption of methylene blue onto hazelnut shell: Kinetics, mechanism and activation parameters. J. Hazard. Mater., 164: 172-181. DOI.org/10.1016/j.jhazmat.2008.07.155

25. Tseng, R.L., 2007. Physical and chemical properties and adsorption type of activated carbon prepared from plum kernels by $\mathrm{NaOH}$ activation. J. Hazard. Mater., 147: 1020-.1027. DOI: 10.1016/j.jhazmat.2007.01.140

26. Robinson, T., B. Chandran and P. Nigam, 2002. Removal of dyes from an artificial textile dye effluent by two agricultural waste residues, corncob and barley husk. Environ. Int., 28: 29-33. DOI: 10.1016/S0160-4120(01)00131-3

27. Hameed, B.H., A.T.M. Din and A.L. Ahmad, 2007. Adsorption of methylene blue onto bamboo-based activated carbon: Kinetics and equilibrium studies J. Hazard. Mater., 141: 819-825. DOI: 10.1016/j.jhazmat.2006.07.049 
28. Hameed, B.H., 2009. Grass waste: A novel sorbent for the removal of basic dye from aqueous solution. J. Hazard. Mater., 166: 233-238. DOI: 10.1016/j.jhazmat.2008.11.019

29. Hameed, B.H. and M.I. El-Khaiary, 2008. Removal of basic dye from aqueous medium using a novel agricultural waste material: Pumpkin seed hull. J. Hazard. Mater., 155: 601-609. DOI: 10.1016/J.JHAZMAT.2007.11.102

30. Hameed, B.H. and A.A. Ahmad, 2009. Batch adsorption of methylene blue from aqueous solution by garlic peel, an agricultural waste biomass. J. Hazard. Mater., 164: 870-875. DOI: 10.1016/j.jhazmat.2008.08.084

31. Hayes, B.B., S. Azadi, R.R. Sullivan and B.J. Meade, 2004. Contact hypersensitivity to methyl red in female Balb/c mice. J. Allergy Clin. Immunol., 113: S57. DOI: 10.1016/J.JACI.2003.12.172

32. Badr, Y., M.G.A. El-Wahed and M.A. Mahmoud, 2008. Photocatalytic degradation of methyl red dye by silica nanoparticles. J. Hazard. Mater., 154: 245-253. DOI: 10.1016/j.jhazmat.2007.10.020

33. So, K., P. Wong and K. Chang, 1990. Decolorization and biodegradation of methyl red by acetobacter liquefaciens. Toxic. Assess., 5: 221-235. DOI: 10.1002/tox.2540050303

34. Wong, P. and P. Yuen, 1998. Decolourization and biodegradation of N,N'-dimethyl-pphenylenediamine by Klebsiella pneumoniae RS13 and Acetobacter liquefaciens S-1. J. Applied Microbiol., 85: 79-87. DOI: 10.1046/j.13652672.1998.00479.x

35. Vijaya, P.P. and S. Sandhya, 2003. Decolorization and complete degradation of methyl red by a mixed culture. Environmentalist, 23: 145-149. DOI: 10.1023/A:1024839805387

36. Jadhav, S.U., S.D. Kalme and S.P. Govindwar, 2008. Biodegradation of methyl red by galactomyces geotrichum MTCC 1360. Int. Biodeter. Biodegr., 62: 135-142. DOI: 10.1016/j.ibiod.2007.12.010

37. Aksu, Z. and G. Donmez, 2003. A comparative study on the biosorption characteristics of some yeasts for Remazol Blue reactive dye. Chemosphere, 50 1075-1083. DOI: 10.1016/S0045-6535(02)00623-9

38. Gupta, V.K., R. Jain, S. Varshney and V.K. Saini, 2007. Removal of Reactofix Navy Blue 2 GFN from aqueous solutions using adsorption techniques. J. Colloid Interface Sci., 307: 326-332. DOI: $10.1016 /$ j.jcis.2006.12.003
39. Malik, P.K., 2004. Dye removal from wastewater using activated carbon developed from sawdust: Adsorption equilibrium and kinetics. J. Hazard. Mater., $\quad$ 113: $81-88 . \quad$ DOI: 10.1016/j.jhazmat.2004.05.022

40. Mohamed, M.M., 2004. Acid dye removal: Comparison of surfactant-modified mesoporous FSM-16 with activated carbon derived from rice husk. J. Colloid Interface Sci., 272:28-34. DOI: 10.1016/j.jcis.2003.08.071

41. Khattri, S.D. and M.K. Singh, 2009. Removal of malachite green from dye wastewater using neem sawdust by adsorption. J. Hazard. Mater., DOI: 10.1016/J.JHAZMAT.2009.01.101

42. Baztias, F.A. and D.K. Sidiras, 2007. Dye adsorption by prehydrolysed beech sawdust in batch and fixed-bed systems. Biores. Technol., 98; 1208-1217. DOI: 10.1016/j.biortech.2006.05.020

43. Mohan, S.V., N.C. Rao and J. Karthikeyan, 2002. Adsorptive removal of direct azo dye from aqueous phase onto coal based sorbents: A kinetic and mechanistic study.J. Hazard. Mater., B90: 189-204. DOI: 10.1016/S0304-3894(01)00348-X

44. Hameed, B.H., D.K. Mahmoud and A.L. Ahmad, 2008. Sorption equilibrium and kinetics of basic dye from aqueous solution using banana stalk waste. J. Hazard. Mater., 158: 499-506. DOI: 10.1016/j.jhazmat.2008.01.098

45. Mittal, A., V.K. Gupta, A. Malviya and J. Mittal, 2008. Process development for the batch and bulk removal and recovery of a hazardous, watersoluble azo dye Metanil Yellow by adsorption over waste materials (bottom ash and de-oiled soya). J. Hazard. Mater., 151: 821-832. DOI: 10.1016/j.jhazmat.2007.06.059

46. Tsai, W.T., K.J. Hsien, H.C. Hsu, C.M. Lin, K.Y. Lin and C.H. Chiu, 2008. Utilization of ground eggshell waste as an adsorbent for the removal of dyes from aqueous solution. Biores. Technol., 99: 1623-1629. DOI: 10.1016/j.biortech.2007.04.010

47. Al-Qodah, Z., 2000. Adsorption of dyes using shale oil ash. Water Res., 34: 4295- 4303. DOI: 10.1016/S0043-1354(00)00196-2

48. Ho, Y.S., C.C. Chiang and Y.C Hsu, 2001. Sorption kinetics for dye removal from aqueous solution using activated clay. Sep. Sci. Technol., 36: 2473-2488. DOI: 10.1081/SS-100106104

49. Tan, I.A.W., A.L. Ahmad and B.H. Hameed, 2008. Adsorption of basic dye using activated carbon prepared from oil palm shell: Batch and fixed bed studies, 225: 13-28. DOI: 10.1016/J.DESAL.2007.07.005 
50. Langmuir, I., 1918. The adsorption of gases on plane surfaces of glass, mica and platinum. J. Am. Chem. Soc. 40: 1361-1403. DOI: 10.1021/ja02242a004

51. Ahmad, A.L., S. Sumathi and B.H. Hameed, 2005. Adsorption of residue oil from palm oil mill effluent using powder and flake chitosan: Equilibrium and kinetic studies. Water Res., 39: 2483-2494. DOI: 10.1016/J.WATRES.2005.03.035

52. Ajmal, M., H.A. Khan, S. Ahmad and A. Ahmad, 1998. Role of sawdust in the removal of copper (II) from industrial wastes. Water Res., 32: 3085-3091. DOI: 10.1016/S0043-1354(98)00067-0

53. Ho, Y.S., 2004. Citation review of Lagergren kinetic rate equation on adsorption reactions. Scientometrics, 59: 171-177. DOI: 10.1023/B:SCIE.0000013305.99473.cf

54. Ho, Y.S. and G. McKay, 1999. A kinetic study of dye sorption by biosorbent waste product pith. Res. Conserv. Recycl., 25: 171-193. DOI: 10.1016/S0921-3449(98)00053-6

55. Bilba, K., M.A. Arsene and A. Ouensanga, 2007. Study of banana and coconut fibers: botanical composition, thermal degradation and textural observations. Biores. Tech., 98: 58-68. DOI: 10.1016/j.biortech.2005.11.030
56. Gurgel, L.V.A., R.P. de Freitas and L.F. Gil, 2008. Adsorption of $\mathrm{Cu}(\mathrm{II}), \mathrm{Cd}(\mathrm{II})$ and $\mathrm{Pb}(\mathrm{II})$ from aqueous single metal solutions by sugarcane bagasse and mercerized sugarcane bagasse chemically modified with succinic anhydride. Carbohyd. Polym., 74: 922-929. DOI: 10.1016/j.carbpol.2008.05.023

57. Sun, R.C., J. Tomkinson, P.L. Ma and S.F. Liang, 2000. Comparative study of hemicelluloses from rice straw by alkali and hydrogen peroxide treatments. Carbohyd. Polym., 42: 111-122. DOI: 10.1016/S0144-8617(99)00136-8

58. Xu, F., J.X. Sun, Z.C. Geng, C.F. Liu, J.L. Ren, R.C. Sun, P. Fowler and M.S. Baird, 2006. Fractional and structural characterization of hemicelluloses from perennial ryegrass (Lolium perenne) and cocksfoot grass (Dactylis glomerata). Carbohyd. Polym., 314: 2073-2082. DOI: 10.1016/J.CARRES.2006.04.033

59. Yang, H., R. Yan, H. Chen, D.H. Lee and C. Zheng, 2007. Characteristics of hemicellulose, cellulose and lignin pyrolysis. Fuel, 86: 1781-1788. DOI: 10.1016/j.fuel.2006.12.013

60. Chaikumpollert, O., P. Methacanon and K. Suchiva, 2004. Structural elucidation of hemicelluloses from Vetiver grass. Carbohyd. Polym., 57: 191-196. DOI: 10.1016/j.carbpol.2004.04.011 